\title{
Investigation of carbonate dissolution for the separation of magnesium hydroxide and calcium sulphate in a magnesium hydroxide-calcium sulphate mixed sludge
}

\author{
TT Rukuni ${ }^{*}$, JP Maree ${ }^{2}$ and FHH Carlsson ${ }^{1}$ \\ 'Department of Environmental, Water and Earth Sciences, Tshwane University of Technology, Private Bag X680, Pretoria, 0001, South Africa \\ ${ }^{2}$ Rand Water Chair in Water Utilisation, Tshwane University of Technology, Private Bag X680, Pretoria, 0001, South Africa
}

\begin{abstract}
South Africa is experiencing a large environmental problem due to uncontrolled discharge of acid mine water into public water courses. The need for neutralisation and desalination of acid mine drainage is a significant issue in South Africa and the sludges that result from mine wastewater treatment usually contain elevated levels of mixed contaminants derived from those originally contained in the wastewater. A more reasonable approach to ultimate sludge disposal is to view the sludge as a resource that can be recycled or reused. Carbon dioxide and a sludge mixture consisting of $\mathrm{Mg}(\mathrm{OH})_{2}$ and $\mathrm{CaSO}_{4} \cdot 2 \mathrm{H}_{2} \mathrm{O}$ are by-products from acid mine drainage treatment processes. This study was carried out to explore the feasibility of separating $\mathrm{Mg}(\mathrm{OH})_{2}$ from $\mathrm{CaSO}_{4} \cdot 2 \mathrm{H}_{2} \mathrm{O}$ through dissolution of $\mathrm{Mg}(\mathrm{OH})_{2}$ by accelerated carbonation in a pressurised, completely-mixed reactor. The effects of temperature and pressure, and of both together, on the dissolution of the sludge mixture with time were investigated. Parameters monitored included alkalinity, $\mathrm{pH}$, conductivity and $\mathrm{Ca}^{2+}, \mathrm{Mg}^{2+}$ and $\mathrm{SO}_{4}^{2-}$ concentrations. OLI Analyser Studio Version 9.0 software was used for modelling predictions of chemical speciation of the mixtures. The optimum separation capacity for the $\mathrm{Mg}(\mathrm{OH})_{2}-\mathrm{CaSO}_{4} \cdot 2 \mathrm{H}_{2} \mathrm{O}$ sludge mixture was determined to be $99.34 \% \mathrm{Mg}^{2+}$ and $0.05 \%$ $\mathrm{Ca}^{2+}$ in the aqueous phase when contacted with $\mathrm{CO}_{2}$ at a temperature of $5^{\circ} \mathrm{C}$ and pressure of $150 \mathrm{kPa}$. The model predictions were in agreement with the experimental findings. Temperature and pressure have a significant impact on the dissolution of the mixed sludges when contacted with $\mathrm{CO}_{2}$
\end{abstract}

Keywords: Carbonation, gypsum, dissolution, reclamation, carbon dioxide, sludge disposal

\section{INTRODUCTION}

South Africa is experiencing large environmental threats and problems due to uncontrolled discharge of acid mine drainage (AMD) into public water courses. The eMalahleni Water Treatment Works (EWTW) treats $50 \mathrm{Ml} / \mathrm{d}$ of acid mine water. Limestone is used in the pre-treatment stage for the removal of acid and metals. Partial sulphate removal is achieved through gypsum crystallisation at $\mathrm{pH}$ 6. Lime is used for the removal of magnesium as $\mathrm{Mg}(\mathrm{OH})_{2}$ and further sulphate removal is achieved through gypsum crystallisation at $\mathrm{pH} 11$. Ultrafiltration and reverse osmosis are used as a final desalination stage. Separation of $\mathrm{Mg}(\mathrm{OH})_{2}$ from gypsum is needed for the CSIR-ABC process as described by Rukuni et al. (2012a; 2012b). A mixed $\mathrm{Mg}(\mathrm{OH})_{2}-\mathrm{CaSO}_{4} \cdot 2 \mathrm{H}_{2} \mathrm{O}$ sludge is produced in the second stage of the process. In order to exploit the potential usefulness of the sludge, it is important to separate individual compounds from one another, such as $\mathrm{Mg}(\mathrm{OH})_{2}$ from $\mathrm{CaSO}_{4} \cdot 2 \mathrm{H}_{2} \mathrm{O}$. Figure 1 shows a schematic diagram of the CSIR-ABC process. Rukuni et al. (2012a and 2012b) have also studied the separation of $\mathrm{CaCO}_{3}-\mathrm{BaSO}_{4}$ and $\mathrm{Mg}(\mathrm{OH})_{2}-\mathrm{BaSO}_{4}$ sludge mixtures in contact with $\mathrm{CO}_{2}$.

The aim of this study was to separate magnesium hydroxide from calcium sulphate through dissolution of $\mathrm{Mg}(\mathrm{OH})_{2}$

This paper was originally presented at the 2014 Water Institute of Southern Africa (WISA) Biennial Conference, Mbombela, 25-29 May 2014.

* To whom all correspondence should be addressed.

e-mail:RukuniTT@tut.ac.za or tece.1997@yahoo.com by accelerated carbonation. By adding $\mathrm{CO}_{2}$ to a $\mathrm{Mg}(\mathrm{OH})_{2}+$ $\mathrm{CaSO}_{4} \cdot 2 \mathrm{H}_{2} \mathrm{O}$ sludge, $\mathrm{Mg}(\mathrm{OH})_{2}$ dissolution occurs according to the following reaction (Rukuni et al., 2012b):

$$
\mathrm{Mg}(\mathrm{OH})_{2(\mathrm{~s})}+\mathrm{CO}_{2(\mathrm{~g})}+\mathrm{H}_{2} \mathrm{O}_{(\mathrm{l})} \rightarrow \mathrm{Mg}^{2+}{ }_{(\mathrm{aq})}+2 \mathrm{HCO}_{3(\mathrm{aq})}^{-}
$$

\section{MATERIALS AND METHODS}

A sludge mixture of $7.78 \% \mathrm{CaSO}_{4} \cdot 2 \mathrm{H}_{2} \mathrm{O}$ and $92.2 \% \mathrm{Mg}(\mathrm{OH})_{2}$ was prepared (mass \%). Commercial grade $\mathrm{Mg}(\mathrm{OH})_{2}(60 \mathrm{~g})$ and $\mathrm{CaSO}_{4} \cdot 2 \mathrm{H}_{2} \mathrm{O}(5.06 \mathrm{~g})$ were used. The reaction vessel was equipped with a BirCraft stirrer, temperature sensor, pressure gauge and in situ $\mathrm{pH}$ and conductivity electrodes. This unit was rated for pressures up to $1000 \mathrm{kPa}$ and a maximum temperature of $150^{\circ} \mathrm{C}$.

The main body of the reactor was constructed from a Class 12 unplasticised polyvinylchloride (uPVC) pipe with a wall thickness of $3.2 \mathrm{~mm}$ and an internal diameter of $560 \mathrm{~mm}$. The length of the pipe was $520 \mathrm{~mm}$ with a uPVC base and top plates that were each $65 \mathrm{~mm}$ thick. The dosage points were $300 \mathrm{~mm}$ above the effluent take-off point that was fitted at the bottom of the reactor. A pressure regulator was used to control $\mathrm{CO}_{2}$ dosage by monitoring the pressure in the reactor.

Magnesium hydroxide and calcium sulphate dihydrate were added to $1 \ell$ of deionised water and pumped into the reaction vessel (Watson-Marlow pump) with continuous stirring. The mixed sludge was contacted with $\mathrm{CO}_{2}$ in the $3 \ell$ completelymixed, pressurised reactor (Fig. 2). Pressurised carbon dioxide was dissolved in water in the pressurised reactor to lower the 


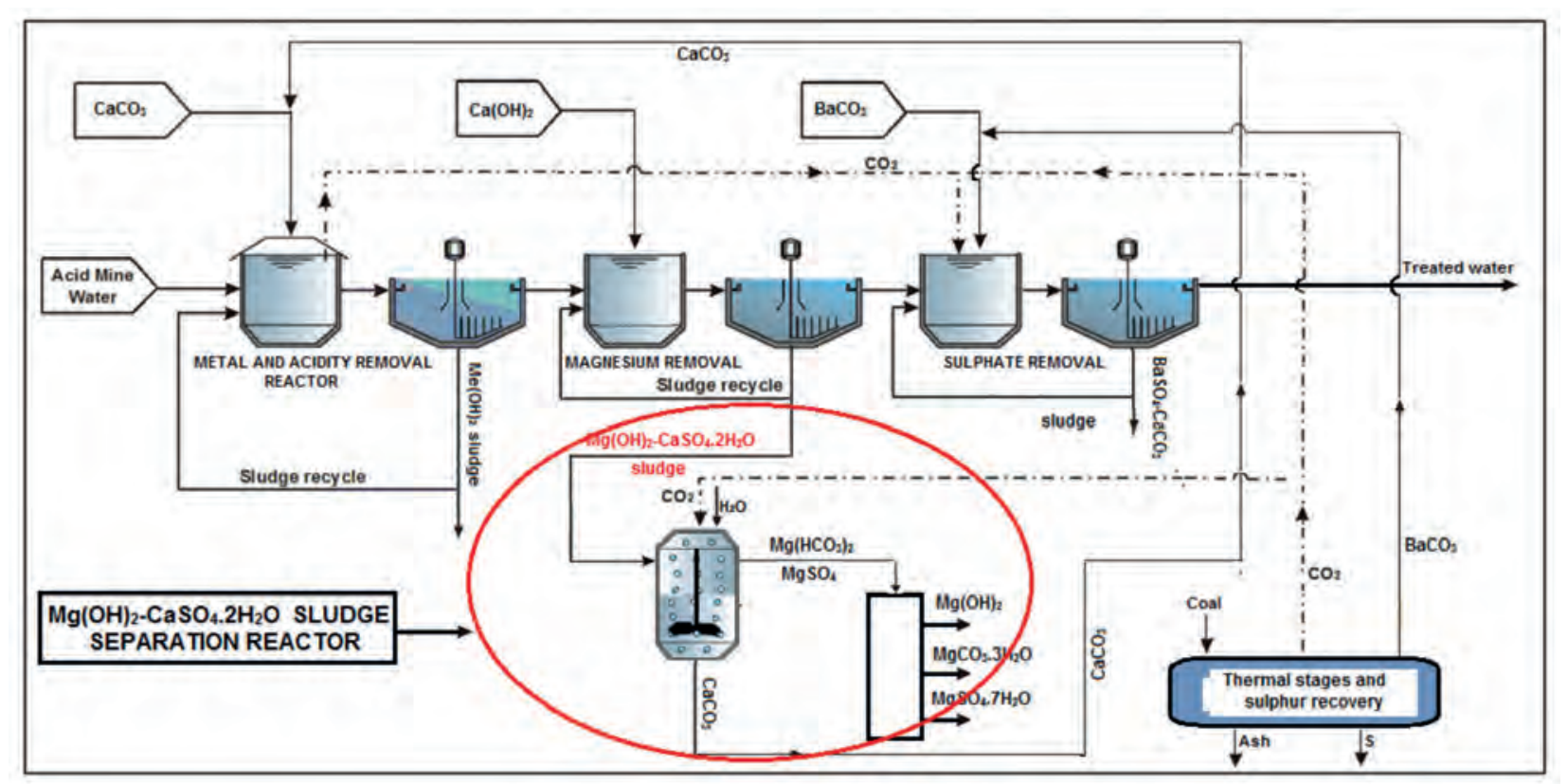

Figure 1

Schematic diagram of the CSIR-ABC process for neutralisation, metal removal and desalination of $A M D$, and the proposed process (circled)

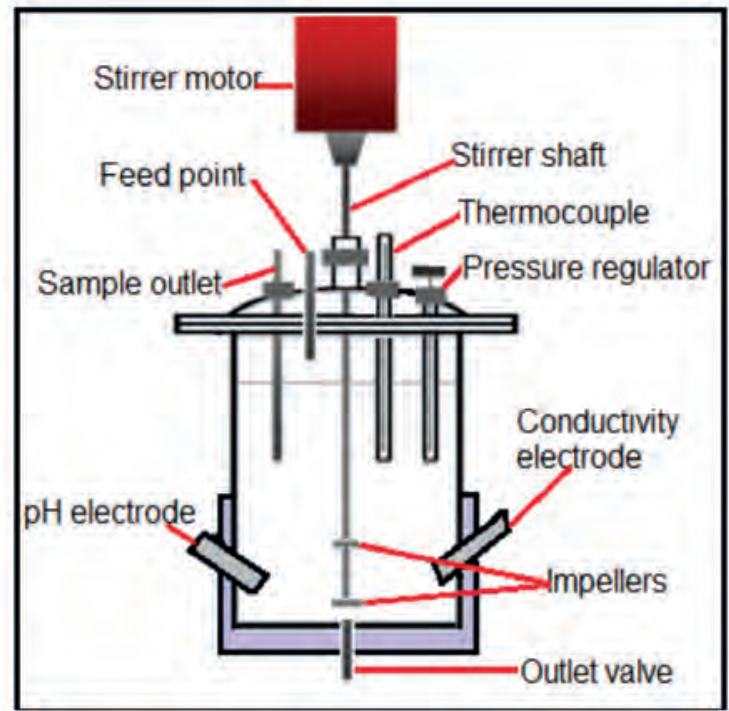

Figure 2

Schematic diagram of the completely-mixed pressurised reactor

$\mathrm{pH}$ and increase the pressure to desired levels. The particles were kept suspended by a shaft stirrer equipped with a disktype, radial-flow impeller at the bottom and an axial flow impeller $50 \mathrm{~mm}$ above the bottom impeller. Surface carbonation of the suspension occurs from the surface area exposure of the liquid to carbon dioxide and this is enhanced by the vortexing action caused by the axial flow impeller.

The $\mathrm{pH}$, temperature, electrical conductivity and pressure were measured in situ at predefined sequences of time steps of $0,10,20,40$ and $60 \mathrm{~min}$. The predicted and measured effect of the following parameters with time was investigated:
- Temperature: $0,10,25,45^{\circ} \mathrm{C}$

- Pressure: 0; 50; 100; 200; 400; 500; 650 kPa

- $\mathrm{Mg}(\mathrm{OH})_{2}$ concentration: $60 \mathrm{~g} / \mathrm{l}$

- $\mathrm{CaSO}_{4} \cdot 2 \mathrm{H}_{2} \mathrm{O}$ concentration: $0,5.06 \mathrm{~g} / \mathrm{\ell}$

Samples were collected regularly and filtered through a $0.45 \mu \mathrm{m}$ membrane filter. Sulphate, alkalinity, and $\mathrm{pH}$ determinations were carried out manually according to standard procedures (Eaton et al., 1995). Calcium and magnesium were analysed using the EDTA method and atomic absorption spectrophotometry. Alkalinity was determined by titrating the solution to pH 4.3 using $0.1 \mathrm{M} \mathrm{HCl}$. No replicates were analysed.

\section{RESULTS AND DISCUSSION}

Figures 3 to 20 show the dissolution of $\mathrm{Mg}(\mathrm{OH})_{2}$ (brucite) and $\mathrm{CaSO}_{4} \cdot 2 \mathrm{H}_{2} \mathrm{O}$ (gypsum) when contacted with $\mathrm{CO}_{2}$ in water under various conditions. Figures 3 to 6 contain the experimental values for the dissolution of gypsum in contact with $\mathrm{CO}_{2}$, while Figs 7 to 11 show the experimental values for the dissolution of $\mathrm{Mg}(\mathrm{OH})_{2}$ in contact with $\mathrm{CO}_{2}$. Figures 12 to 20 show the experimental and predicted findings on the mixed sludge in contact with $\mathrm{CO}_{2}$. Alkalinity (Alk) measurements were used to monitor the formation of $\mathrm{Mg}\left(\mathrm{HCO}_{3}\right)_{2}$ and $\mathrm{Ca}\left(\mathrm{HCO}_{3}\right)_{2}$ and include the parameters listed in Eq. (2). As the system became enriched with $\mathrm{CO}_{2}$, the extent of dissolution decreased as a function of changes in the $\mathrm{Mg}(\mathrm{OH})_{2}$ or $\mathrm{CaSO}_{4} \cdot 2 \mathrm{H}_{2} \mathrm{O}$ saturation state, to yield both magnesium and calcium ions and alkalinity (Rukuni et al., 2012a, Rukuni et al., 2012b).

$$
\mathrm{Alk}=2\left[\mathrm{CO}_{3}^{2-}\right]+\left[\mathrm{HCO}_{3}^{-}\right]+\left[\mathrm{OH}^{-}\right]+\left[\mathrm{H}^{+}\right]
$$




\section{Dissolution of $\mathrm{CaSO}_{4} \cdot 2 \mathrm{H}_{2} \mathrm{O}$ in contact with $\mathrm{CO}_{2}$}

\section{Effect of temperature}

Figure 3 shows that the solubility of gypsum in contact with $\mathrm{CO}_{2}$ decreased with decreasing temperature and vice versa. The highest solubility values of $2000 \mathrm{mg} / \ell\left(\mathrm{as} \mathrm{CaCO}_{3}\right)$ were recorded at $45^{\circ} \mathrm{C}$ compared to $430 \mathrm{mg} / \ell\left(\right.$ as $\mathrm{CaCO}_{3}$ ) at $25^{\circ} \mathrm{C}$. Our findings were consistent with those of Al-Khadi et al. (2011) who reported that an increase in temperature from $25^{\circ} \mathrm{C}$ to $50^{\circ} \mathrm{C}$ resulted in a corresponding increase in gypsum dissolution, when they investigated the dissolution of gypsum in $\mathrm{HCl}$.

The dissolution of gypsum provided a discernible amount of dissolved calcium and sulphates $\left(151.8 \mathrm{mg} / \ell\right.$ as $\left.\mathrm{CaCO}_{3}\right)$ in solution in $10 \mathrm{~min}$ (Fig. 4) at a temperature of $10^{\circ} \mathrm{C}$ and was then stable for the remaining $50 \mathrm{~min}$ of the reaction time. Figure 4 also shows that the solution $\mathrm{pH}$ was stable between 5 and 6. This was attributed to the existence of an unstable layer and fine particle removal from the crystal surface following the transition state theory, while obeying the Power Law (Rukuni et al., 2012b). Raju and Atkinson (1990) and Colombani (2008) reported gypsum solubility in pure water to be: $\mathrm{C}_{\text {sat }}=15 \mathrm{mmol} / \ell$.

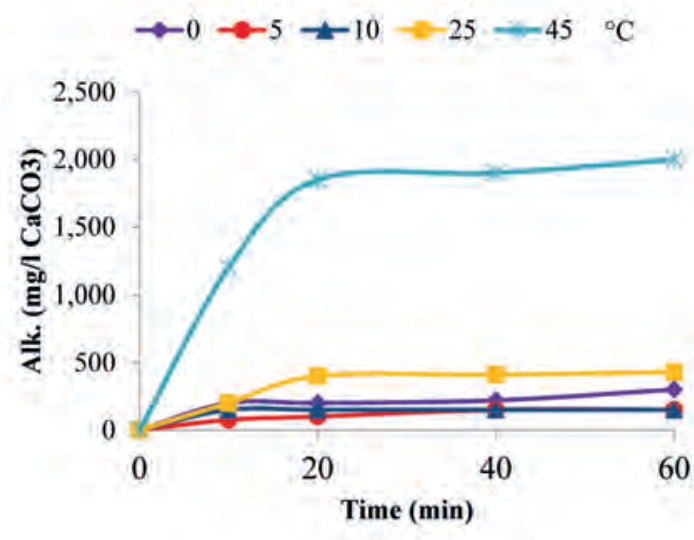

Figure 3

The effect of temperature on the dissolution of $\mathrm{CaSO}_{4} \cdot 2 \mathrm{H}_{2} \mathrm{O}(20 \mathrm{~g} / \mathrm{l})$ in contact with $\mathrm{CO}_{2}$

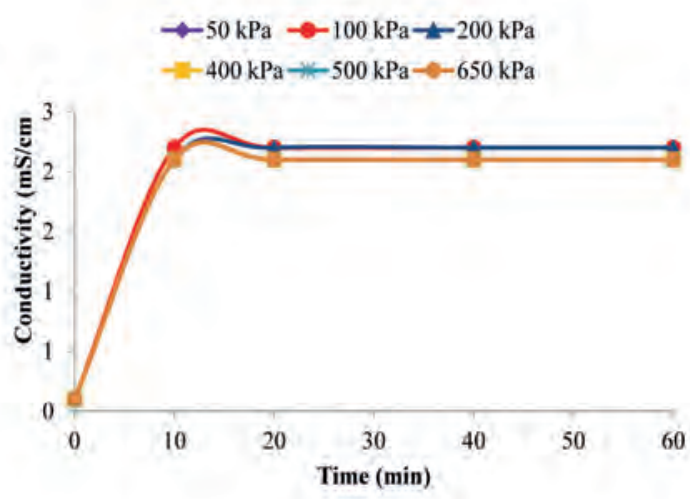

Figure 5

Effect of pressure on the dissolution of $\mathrm{CaSO}_{4} \cdot 2 \mathrm{H}_{2} \mathrm{O}$ in contact with $\mathrm{CO}_{2}$ at $25^{\circ} \mathrm{C}\left(2 \mathrm{Og} / \mathrm{C} \mathrm{CaSO} \mathrm{C}_{4} \cdot 2 \mathrm{H}_{2} \mathrm{O}\right)$
In the current studies, the calculated solubility of $\mathrm{CaSO}_{4} \cdot 2 \mathrm{H}_{2} \mathrm{O}$ in carbonated systems at $45^{\circ} \mathrm{C}$ was $20 \mathrm{mmol} / \ell$. This increase in solubility was attributed to the decrease in water activity by addition of $\mathrm{CO}_{2}$ which led to the observed increase in gypsum solubility. The observed decrease in calcium sulphate solubility at temperatures below $45^{\circ} \mathrm{C}$ was explained by either an overcompensating increase in activity coefficients of calcium and/or sulphate, as reported by Martynowics et al., (1996) or that the $\mathrm{pH}$ was not low enough to increase the solubility (Carlberg and Matthews, 1973; Delorey et al., 1996).

\section{Effect of pressure}

Figure 5 shows the effect of pressure on the dissolution of gypsum in contact with $\mathrm{CO}_{2}$ and demonstrated that a pressure increase from 50 and $650 \mathrm{kPa}$ had no impact on the dissolution rate at $25^{\circ} \mathrm{C}$. Figure 6 illustrates the influence of pressure on $\mathrm{pH}$ and electrical conductivity at 50 and $650 \mathrm{kPa}$ and the values were almost the same while following the same trend. The equilibrium conductivity values in the carbonated system increased from $0 \mathrm{mS} / \mathrm{cm}$ to $2.2 \mathrm{mS} / \mathrm{cm}$ in the initial $10 \mathrm{~min}$ of the reaction and then remained constant for the last $50 \mathrm{~min}$, throughout the pressure range. The measured conductivity was

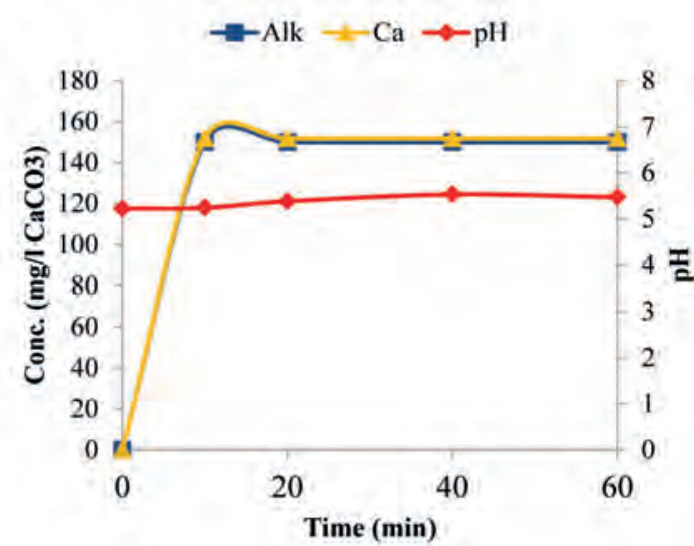

Figure 4

Behaviour of various parameters during contact between $\mathrm{CaSO}_{4} \cdot 2 \mathrm{H}_{2} \mathrm{O}$ and $\mathrm{CO}_{2}\left(\mathrm{Temp}=10^{\circ} \mathrm{C} ; 2 \mathrm{~g} / \mathrm{l} \mathrm{CaSO}_{4} \cdot 2 \mathrm{H}_{2} \mathrm{O}\right)$

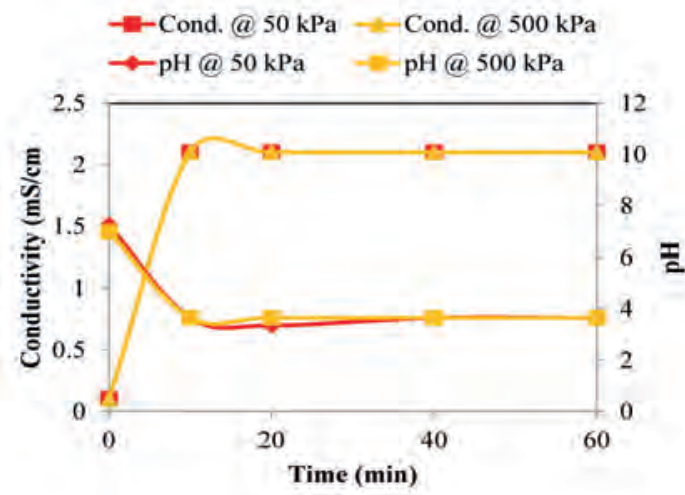

Figure 6

Behaviour of various parameters during contact between $\mathrm{CaSO}_{4} \cdot 2 \mathrm{H}_{2} \mathrm{O}$ and $\mathrm{CO}_{2}$ at $25^{\circ} \mathrm{C}$ (Pressure $=50$ and $500 \mathrm{kPa} ; 20 \mathrm{~g} / \mathrm{l} \mathrm{CaSO} \mathrm{C}_{4} \cdot 2 \mathrm{H}_{2} \mathrm{O}$ ) 
in good agreement with the calculated value of $\mathrm{k}=2.15 \mathrm{mS} / \mathrm{cm}$ in pure water (Kuechler et al., 2004).

\section{Dissolution of $\mathrm{Mg}(\mathrm{OH})_{2}$ in contact with $\mathrm{CO}_{2}$}

\section{Effect of temperature}

The dissolution rate of $\mathrm{Mg}(\mathrm{OH})_{2}$ increased with decreasing temperature as shown in Fig. 7. We also observed that the concentration of $\mathrm{Mg}^{2+}$ in solution increased to almost $36000 \mathrm{mg} / \ell$ (as $\mathrm{CaCO}_{3}$ ) in the first $20 \mathrm{~min}$ and then dropped to $22000 \mathrm{mg} / \mathrm{\ell}$ (as $\mathrm{CaCO}_{3}$ ) in the last $20 \mathrm{~min}$ of the reaction. The maximum solubility value of $36000 \mathrm{mg} / \mathrm{l}$ in the early stages of the reaction could be explained by the high solubility of $\mathrm{Mg}\left(\mathrm{HCO}_{3}\right)_{2}$, the intermediate product when $\mathrm{Mg}(\mathrm{OH})_{2}$ is contacted with $\mathrm{CO}_{2}$.

The $\mathrm{Mg}\left(\mathrm{HCO}_{3}\right)_{2}$ will react further with other species in the system to form artinite, brucite, hydromagnesite, magnesite, magnesium carbonate, nesquehonite and periclase (Rukuni et al., 2012b). The Visual Minteq Model was also used in previous studies which reported that some of these compounds exceeded their solubilities as indicated by the positive saturation index values (Rukuni et al., 2012b). The precipitation of these oversaturated compounds would explain the observed

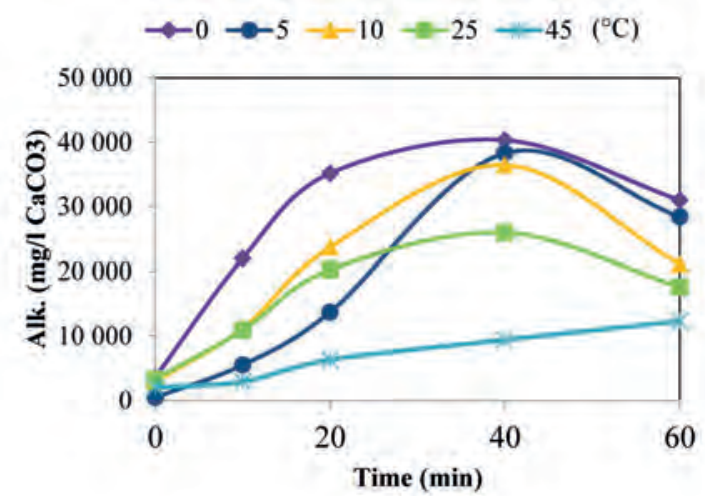

Figure 7

Effect of temperature on the rate of formation and solubility of $\mathrm{Mg}\left(\mathrm{HCO}_{3}\right)_{2}$ in contact with $\mathrm{CO}_{2}\left(60 \mathrm{~g} / \mathrm{l} \mathrm{Mg}(\mathrm{OH})_{2}\right)$

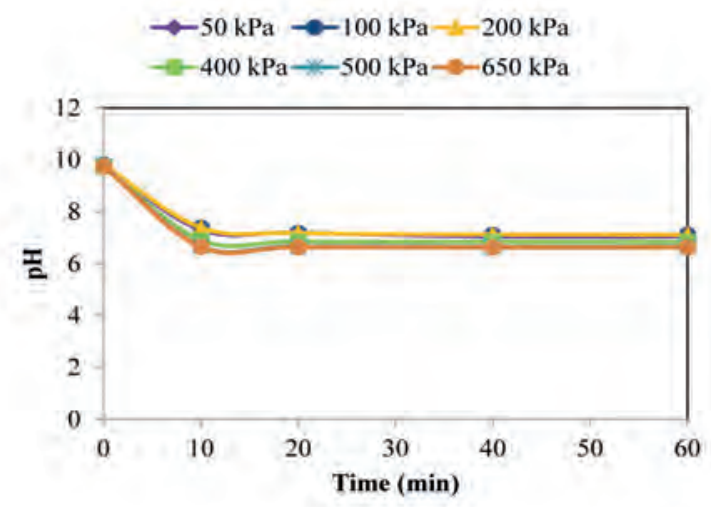

Figure 9

Effect of pressure on the rate of formation and solubility of $\mathrm{Mg}\left(\mathrm{HCO}_{3}\right)_{2}$ in contact with $\mathrm{CO}_{2}$ at $25^{\circ} \mathrm{C}\left(60 \mathrm{~g} / \mathrm{l} \mathrm{Mg}(\mathrm{OH})_{2}\right)$ drop in $\mathrm{Mg}\left(\mathrm{HCO}_{3}\right)_{2}$ concentration in solution from 36000 to $22000 \mathrm{mg} / \mathrm{l} \mathrm{Mg}\left(\mathrm{HCO}_{3}\right)_{2}\left(\right.$ as $\left.\mathrm{CaCO}_{3}\right)$.

Figure 8 shows the ionic balance between the measured magnesium concentration and the total alkalinity of the system. Over the same period the $\mathrm{pH}$ dropped from 9.6 to 7.6 in the first $20 \mathrm{~min}$ and stabilised towards the end of the reaction. This confirmed that most of the reaction occurs in the initial $20 \mathrm{~min}$ and the further addition of $\mathrm{CO}_{2}$ did not further lower the $\mathrm{pH}$. The dissolution of $\mathrm{Mg}(\mathrm{OH})_{2}$ increased with decreased $\mathrm{pH}$ due to the increased formation of soluble $\mathrm{Mg}\left(\mathrm{HCO}_{3}\right)_{2}$. Therefore, $\mathrm{CO}_{2}$ dosing lowered the $\mathrm{pH}$, and magnesium hydroxide was converted to $\mathrm{Mg}\left(\mathrm{HCO}_{3}\right)_{2}$.

\section{Effect of pressure}

The effect of pressure on the dissolution of $\mathrm{Mg}(\mathrm{OH})_{2}$ was studied at $25^{\circ} \mathrm{C}$. The findings plotted in Fig. 9 show that there was no discernible increase in either the dissolution rate or the solution conductivity in the pressure range of 50 to $650 \mathrm{kPa}$. This was also confirmed by the data plotted in Fig. 10 when the $\mathrm{pH}$ and conductivities at 50 and $650 \mathrm{kPa}$ were compared, with no observed changes in the conductivities, $\mathrm{pH}$ values or the trends.

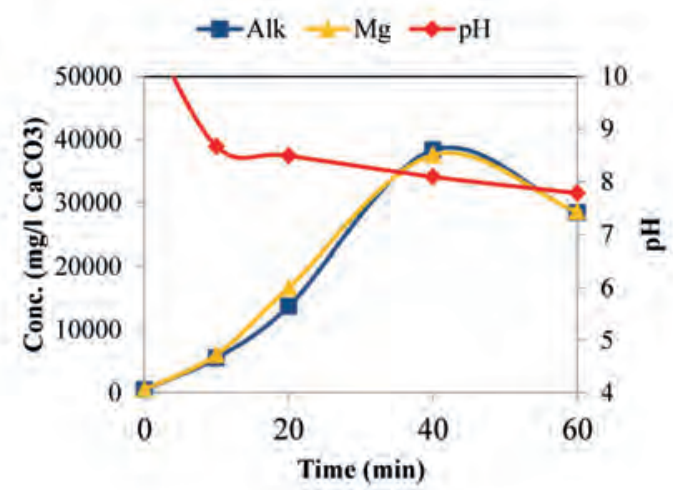

Figure 8

Behaviour of various parameters during contact between $\mathrm{Mg}(\mathrm{OH})_{2}$ and $\mathrm{CO}_{2}\left(\mathrm{Temp}=10^{\circ} \mathrm{C} ; 60 \mathrm{~g} / \mathrm{l} \mathrm{Mg}(\mathrm{OH})_{2}\right)$

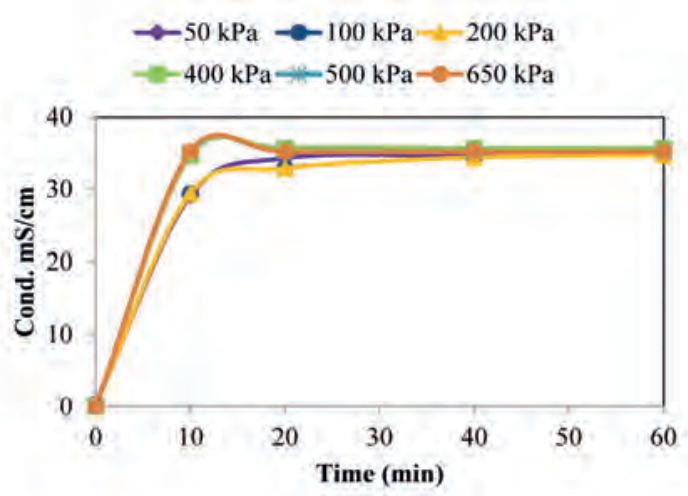

Figure 10

$\mathrm{pH}$ trends during contact between $\mathrm{Mg}(\mathrm{OH})_{2}$ and $\mathrm{CO}_{2}$ at $25^{\circ} \mathrm{C}(60 \mathrm{~g} / \mathrm{l}$ $\left.\mathrm{Mg}(\mathrm{OH})_{2}\right)$ and at various pressures 


\section{Dissolution of a $\mathrm{Mg}(\mathrm{OH})_{2}-\mathrm{CaSO}_{4} \cdot 2 \mathrm{H}_{2} \mathrm{O}$ mixture in contact with $\mathrm{CO}_{2}$}

\section{Effect of temperature}

Figure 11 compares the dissolution rates of $\mathrm{Mg}(\mathrm{OH})_{2}$ with $\mathrm{CaSO}_{4} \cdot 2 \mathrm{H}_{2} \mathrm{O}$, both in contact with $\mathrm{CO}_{2}$. The results show that the former is more soluble. The dissolution of $\mathrm{Mg}(\mathrm{OH})_{2}$ in contact with $\mathrm{CO}_{2}$ was investigated in the presence and absence of $\mathrm{CaSO}_{4} \cdot 2 \mathrm{H}_{2} \mathrm{O}$ at $5^{\circ} \mathrm{C}$. The data plotted in Fig. 12 show that the presence of $\mathrm{CaSO}_{4} \cdot 2 \mathrm{H}_{2} \mathrm{O}$ suppressed precipitation of magnesium compounds that resulted in the decrease of $\mathrm{Mg}\left(\mathrm{HCO}_{3}\right)_{2}$ concentration towards the end of the reaction time.

The mixed $\mathrm{Mg}(\mathrm{OH})_{2}$ and $\mathrm{CaSO}_{4} \cdot 2 \mathrm{H}_{2} \mathrm{O}$ sludge produced by the CSIR-ABC process cannot be separated by solubility differences due to the low solubility of both $\mathrm{Mg}(\mathrm{OH})_{2}(3.8 \mathrm{mg} / \ell$ $\left.\mathrm{Mg}(\mathrm{OH})_{2}\right)$ and $\mathrm{CaSO}_{4} \cdot 2 \mathrm{H}_{2} \mathrm{O}(2.0 \mathrm{~g} / \ell)$. As $\mathrm{CO}_{2}$ is produced as a waste product in the CSIR-ABC process, it was decided to investigate whether $\mathrm{Mg}(\mathrm{OH})_{2}$ could be separated from the almost sparingly soluble $\mathrm{CaSO}_{4} \cdot 2 \mathrm{H}_{2} \mathrm{O}$ by dissolving it as $\mathrm{Mg}\left(\mathrm{HCO}_{3}\right)_{2}$ (Rukuni et al., 2012a; Rukuni et al., 2012b), by

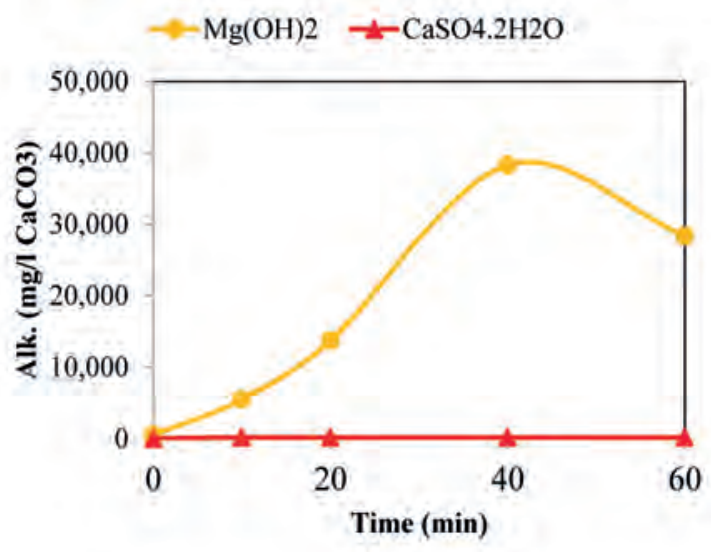

Figure 11

Comparison between dissolution rates of $\mathrm{Mg}(\mathrm{OH})_{2}$ and $\mathrm{CaSO}_{4} \cdot 2 \mathrm{H}_{2} \mathrm{O}$ in a $\mathrm{CO}_{2}$-rich solution $\left(5^{\circ} \mathrm{C} ; 60 \mathrm{~g} / \mathrm{l} \mathrm{Mg}(\mathrm{OH})_{2} ; 20 \mathrm{~g} / \mathrm{l} \mathrm{CaSO}_{4} \cdot 2 \mathrm{H}_{2} \mathrm{O}\right)$

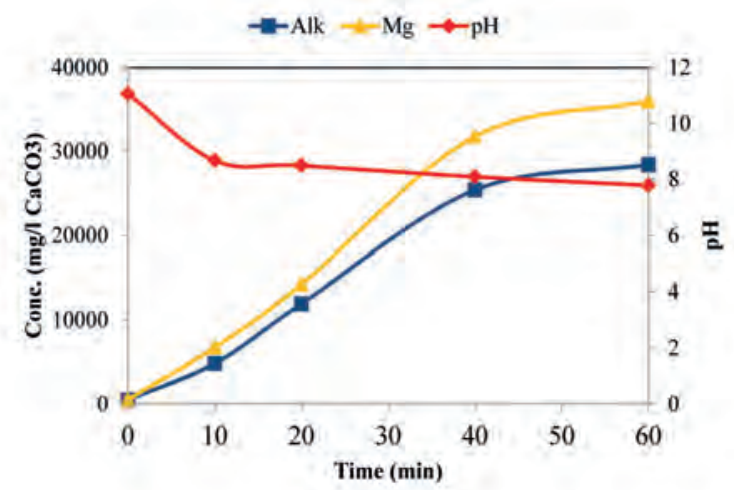

Figure 13

Behaviour of various parameters during contact between $\mathrm{Mg}(\mathrm{OH})_{2^{\prime}}$ $\mathrm{CaSO}_{4} \cdot 2 \mathrm{H}_{2} \mathrm{O}$ and $\mathrm{CO}_{2}\left(\mathrm{Temp}=10^{\circ} \mathrm{C} ; 60 \mathrm{~g} / \mathrm{l} \mathrm{Mg}(\mathrm{OH})_{2} ; 5 \mathrm{~g} / \mathrm{l} \mathrm{CaSO} \mathrm{C}_{4} \cdot 2 \mathrm{H}_{2} \mathrm{O}\right)$ at $100 \mathrm{kPa}$ contacting the sludge mixture with $\mathrm{CO}_{2}$. The chemical reaction of the sludge mixture with $\mathrm{CO}_{2}$ is shown in Eq. (3) (Bishop, 1943).

$$
\begin{aligned}
& 2 \mathrm{CaSO}_{4} \cdot 2 \mathrm{H}_{2} \mathrm{O}+2 \mathrm{Mg}(\mathrm{OH})_{2}+3 \mathrm{CO}_{2} \rightarrow \mathrm{CaSO}_{4}+\mathrm{CaCO}_{3} \\
& +\mathrm{Mg}\left(\mathrm{HCO}_{3}\right)_{2}+\mathrm{MgSO}_{4}+3 \mathrm{H}_{2} \mathrm{O}
\end{aligned}
$$

Figure 13 shows that the concentration of $\mathrm{Mg}^{2+}$ ions was $36000 \mathrm{mg} / \ell\left(\mathrm{as} \mathrm{CaCO}_{3}\right)$ in the form of $\mathrm{MgSO}_{4}$ and $\mathrm{Mg}\left(\mathrm{HCO}_{3}\right)_{2}$. This concentration was higher than the aqueous concentration of $\mathrm{Mg}^{2+}$ ions when $\mathrm{Mg}(\mathrm{OH})_{2}$ alone was contacted with $\mathrm{CO}_{2}$, as shown in Fig. 8. This was due to the presence of sulphate ions which suppressed the precipitation of the other magnesium compounds (artinite, brucite, hydromagnesite, magnesite and periclase) except for nesquehonite. This was confirmed by the speciation of the aqueous and solid species, depicted in Figs 17 and 18 , respectively.

The total alkalinity of the system increased with decreasing temperature as shown in Fig. 14 and this followed the same trend as in Fig. 7 when $\mathrm{Mg}(\mathrm{OH})_{2}$ alone was contacted with $\mathrm{CO}_{2}$. The only difference between these 2 graphs (Figs 7 and 14) is

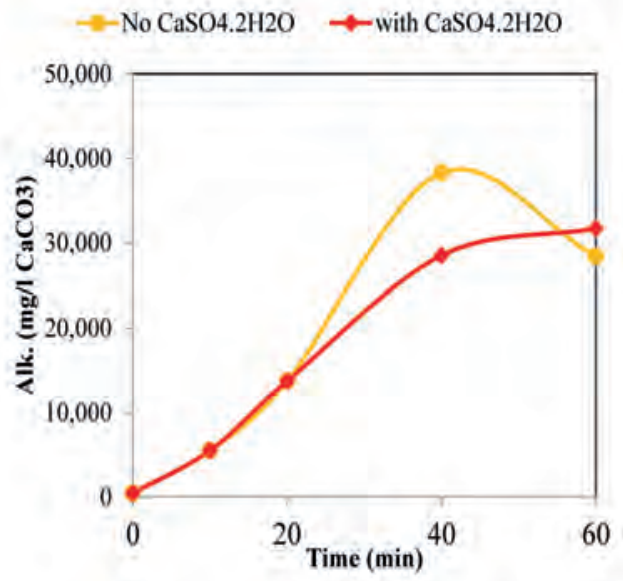

Figure 12

The effect of $\mathrm{Ca}^{2+}$ on the solubility and rate of formation of $\mathrm{Mg}\left(\mathrm{HCO}_{3}\right)_{2}$ in contact with $\mathrm{CO}_{2}$ at $5^{\circ} \mathrm{C}\left(60 \mathrm{~g} / \mathrm{l} \mathrm{Mg}(\mathrm{OH})_{2}\right.$ and no CaSO $\cdot 2 \mathrm{H}_{2} \mathrm{O}$ and $60 \mathrm{~g} / \mathrm{l}$ $\mathrm{Mg}(\mathrm{OH})_{2}$ with $\left.5 \mathrm{~g} / \ell \mathrm{CaSO}_{4} \cdot 2 \mathrm{H}_{2} \mathrm{O}\right)$

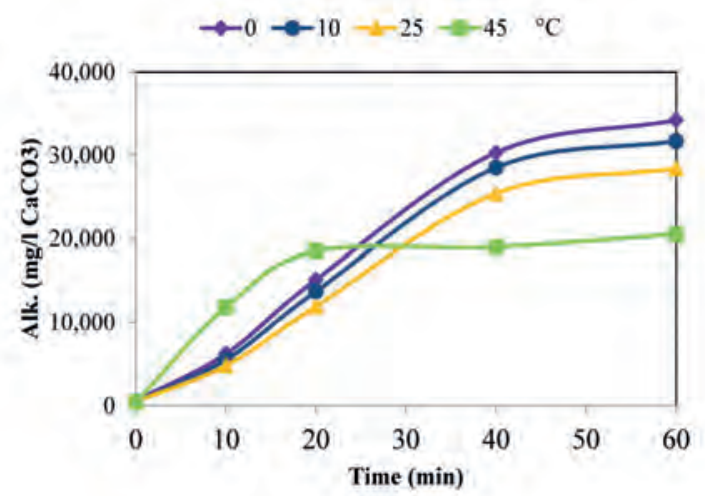

Figure 14

Effect of temperature on the rate of formation and solubility of $\mathrm{Mg}\left(\mathrm{HCO}_{3}\right)_{2}$ in contact with $\mathrm{CO}_{2}$ at $100 \mathrm{kPa}$ in the presence of $\mathrm{CaSO} 4 \cdot 2 \mathrm{H}_{2} \mathrm{O}$ $\left(60 \mathrm{~g} / \ell \mathrm{Mg}(\mathrm{OH})_{2} ; 5 \mathrm{~g} / \mathrm{l} \mathrm{CaSO}_{4} \cdot 2 \mathrm{H}_{2} \mathrm{O}\right)$ 
the absence of the final decrease in temperature in Fig. 7. The absence of $\mathrm{Ca}^{2+}$ in solution was attributed to the formation of $\mathrm{CaCO}_{3}$ and $\mathrm{MgSO}_{4}$ after the dissolution of $\mathrm{CaSO}_{4} \cdot 2 \mathrm{H}_{2} \mathrm{O}$.

\section{The effect of pressure}

The results presented in Figs 15 and 16 show no change in the conductivity and $\mathrm{pH}$ when the pressure was varied between 50 and $650 \mathrm{kPa}$ at $25^{\circ} \mathrm{C}$. The maximum conductivity in Fig. 15 was comparable to that in Fig. 9, when $\mathrm{Mg}(\mathrm{OH})_{2}$ was investigated. This suggests that the reactions taking place in this system were due to the dissolution of $\mathrm{Mg}(\mathrm{OH})_{2}$ as $\mathrm{Mg}\left(\mathrm{HCO}_{3}\right)_{2}$.

Based on model calculations using OLI Analyzer Studio Version 9.0 software, Figs 17 and 18 show the effects of pressure on the dissolution of $\mathrm{Mg}(\mathrm{OH})_{2}$ and $\mathrm{CaSO}_{4} \cdot 2 \mathrm{H}_{2} \mathrm{O}$ in contact with $\mathrm{CO}_{2}$ at $25^{\circ} \mathrm{C}$. The results show that most of the $\mathrm{Mg}$ would be in solution in the form of $\mathrm{MgOH}^{+}$and $\mathrm{MgHCO}_{3}{ }^{+}$while nearly all of the dissolved calcium would be precipitated as $\mathrm{CaCO}_{3}$ (Fig. 18). The amount of $\mathrm{Mg}$ species in solution increased linearly between 1 and $650 \mathrm{kPa}$ and will be constant $\left(110000 \mathrm{MgOH}^{+}\right.$ and $90000 \mathrm{mg} / \ell \mathrm{MgHCO}_{3}^{+}$) from 800 to $1500 \mathrm{kPa}$.

Although most of the calcium was precipitated as $\mathrm{CaCO}_{3}$ and $\mathrm{CaSO}_{4}$, nesquehonite $\left(\mathrm{MgCO}_{3} \cdot 3 \mathrm{H}_{2} \mathrm{O}\right)$ constituted the larger percentage of the solids at pressures between 101 and $304 \mathrm{kPa}$. All nesquehonite will be in solution at pressures above $300 \mathrm{kPa}$ and the solids will be mainly $\mathrm{CaSO}_{4}$ and $\mathrm{CaCO}_{3}$. The $\mathrm{CaSO}_{4}$ concentration also dropped with increasing pressure to zero at $800 \mathrm{kPa}$. The drop in $\mathrm{MgCO}_{3} \cdot 3 \mathrm{H}_{2} \mathrm{O}$ and $\mathrm{CaSO}_{4}$ content in the solid phase may lead to the formation of $\mathrm{CaMg}\left(\mathrm{SO}_{4}\right)_{2}$ as shown in the reaction (Eq. (4)):

$$
\begin{aligned}
& 2 \mathrm{CaSO}_{4}+\mathrm{MgCO}_{3} \cdot 3 \mathrm{H}_{2} \mathrm{O}+\mathrm{CO}_{2} \rightarrow \mathrm{Ca}\left(\mathrm{HCO}_{3}\right)_{2} \\
& +\mathrm{CaMg}\left(\mathrm{SO}_{4}\right)_{2}+2 \mathrm{H}_{2} \mathrm{O}
\end{aligned}
$$

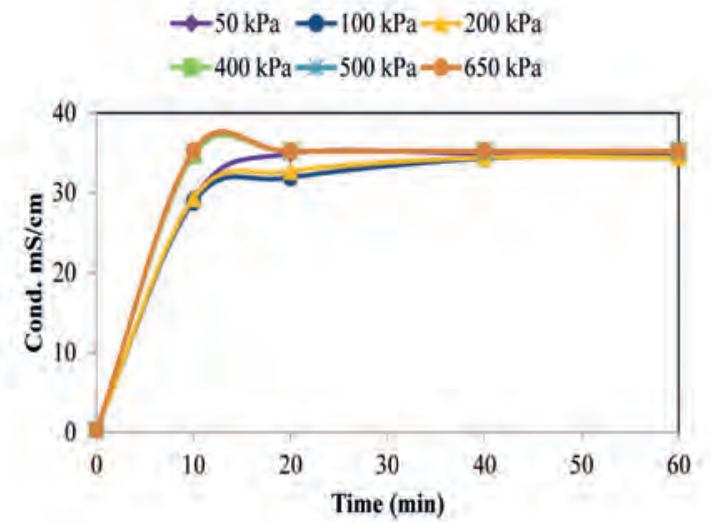

Figure 15

Effect of pressure on the rate of formation and solubility of $\mathrm{Mg}\left(\mathrm{HCO}_{3}\right)_{2}$ in contact with $\mathrm{CO}_{2}$ at $25^{\circ} \mathrm{C}$ in the presence of $\mathrm{CaSO}_{4} \cdot 2 \mathrm{H}_{2} \mathrm{O}\left(60 \mathrm{~g} / \mathrm{l} \mathrm{Mg}(\mathrm{OH})_{2}\right.$; $\left.5 \mathrm{~g} / \mathrm{l} \mathrm{CaSO}_{4} \cdot 2 \mathrm{H}_{2} \mathrm{O}\right)$

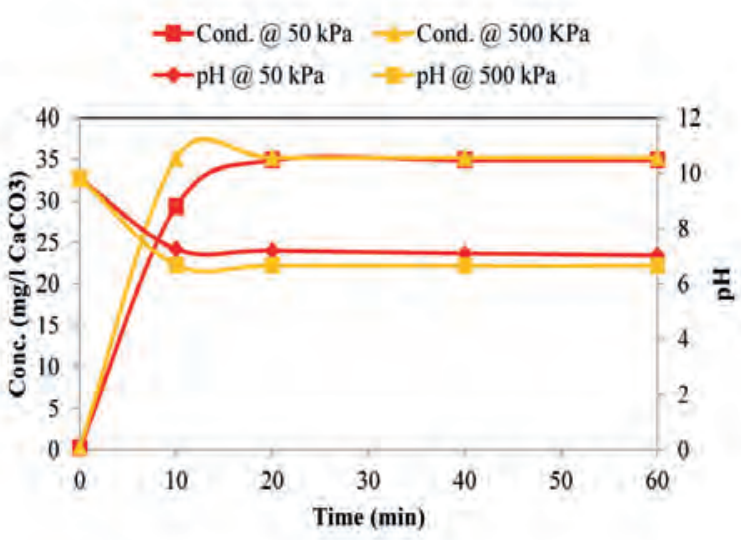

Figure 16

Behaviour of $\mathrm{pH}$ and conductivity during contact between $\mathrm{Mg}(\mathrm{OH})_{2^{\prime}}$ $\mathrm{CaSO}_{4} \cdot 2 \mathrm{H}_{2} \mathrm{O}$ and $\mathrm{CO}_{2}$ at $25^{\circ} \mathrm{C}$ (Pressure $=50$ and $500 \mathrm{kPa} ; 60 \mathrm{~g} / \mathrm{l} \mathrm{Mg}(\mathrm{OH})_{2}$ $5 \mathrm{~g} / \mathrm{l} \mathrm{CaSO}_{4} \cdot 2 \mathrm{H}_{2} \mathrm{O}$ ).

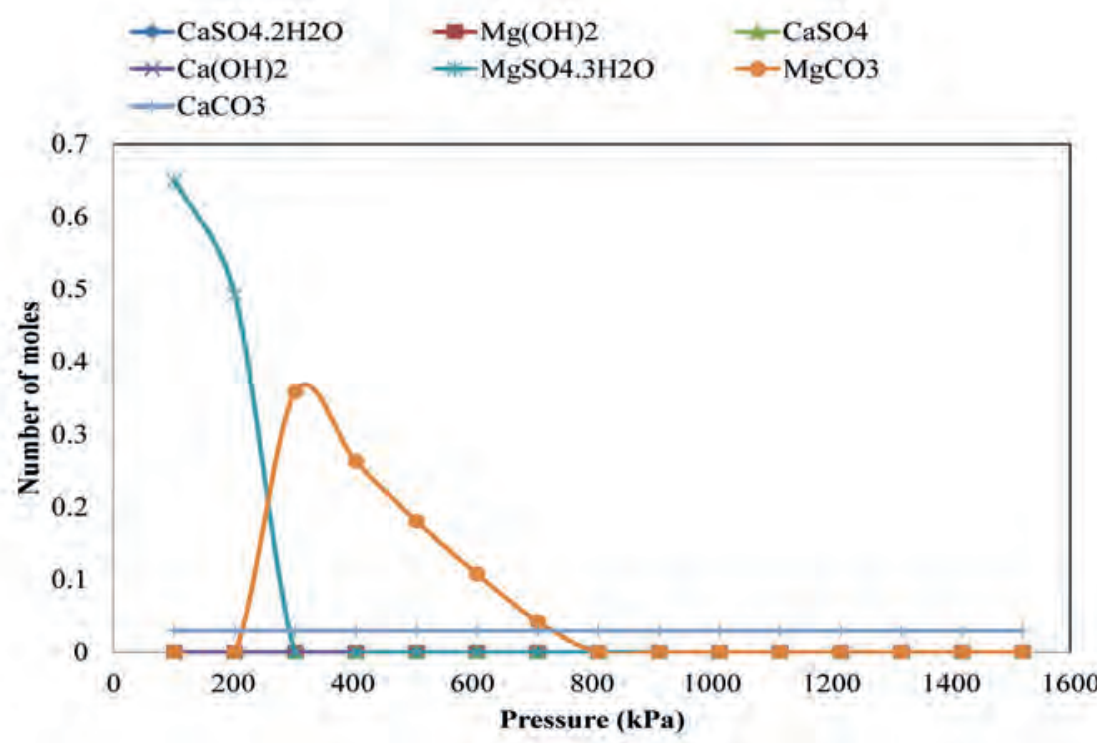

Figure 17

Quantitative speciation modelling in the aqueous phase $\left(60 \mathrm{~g} / \mathrm{l} \mathrm{Mg}(\mathrm{OH})_{2} ; 5.06 \mathrm{~g} \mathrm{CaSO} \mathrm{C}_{4} \cdot 2 \mathrm{H}_{2} \mathrm{O}\right.$ at $\left.25^{\circ} \mathrm{C}\right)$ 
The amount of $\mathrm{CaCO}_{3}$ in solution remained almost constant throughout the pressure range.

\section{The separation of $\mathrm{Mg}(\mathrm{OH})_{2}$ and $\mathrm{CaSO}_{4} \cdot 2 \mathrm{H}_{2} \mathrm{O}$}

Figure 19 compares the total amount of $\mathrm{Mg}$ and $\mathrm{Ca}$ ions in the system, by mass, to the amount of these ions in the aqueous phase at a fixed temperature of $5^{\circ} \mathrm{C}$. Figure 20 compares the ions at a fixed pressure of $150 \mathrm{kPa}$. Figure 19 shows that $99.34 \%$ of the system's $25005 \mathrm{mg} / \ell \mathrm{Mg}$ was in solution at $150 \mathrm{kPa}$ when the temperature was maintained at $5^{\circ} \mathrm{C}$, and all of the $\mathrm{Mg}$ was in solution at pressures from 2 to $650 \mathrm{kPa}$. Figure 20 shows that when pressure is fixed at $150 \mathrm{kPa}, 100 \%(25005 \mathrm{mg} / \mathrm{\ell}$
$\mathrm{Mg}$ ) of the dosed $\mathrm{Mg}$ ions were in solution at $0^{\circ} \mathrm{C}$, and $99.34 \%$ $\left(24840 \mathrm{mg} / \ell \mathrm{Mg}\right.$ ) were in solution at $5^{\circ} \mathrm{C}$. In the case of $\mathrm{Ca}$ ions, $1.14 \%$ by mass of the total $1164 \mathrm{mg} / \ell$ Ca was dissolved and will be the major impurity in the dissolved $\mathrm{Mg}(\mathrm{HCO})_{3}$. The $\mathrm{Ca}^{2+}$ impurity in the recovered $\mathrm{Mg}^{2+}$ constitutes $0.05 \%$ by mass.

These results suggest that the dissolution of calcium sulphate in carbonate systems occurs in the following manner:

$$
\begin{aligned}
& \mathrm{CaSO}_{4} \cdot 2 \mathrm{H}_{2} \mathrm{O}+2 \mathrm{CO}_{2} \rightarrow \mathrm{Ca}\left(\mathrm{HCO}_{3}\right)_{2}+\mathrm{H}_{2} \mathrm{SO}_{4} \\
& \mathrm{H}_{2} \mathrm{SO}_{4} \rightarrow \mathrm{H}^{+}+\mathrm{HSO}_{4}^{-} \\
& \mathrm{HSO}_{4}^{-} \rightarrow \mathrm{H}^{+}+\mathrm{SO}_{4}^{2-}
\end{aligned}
$$

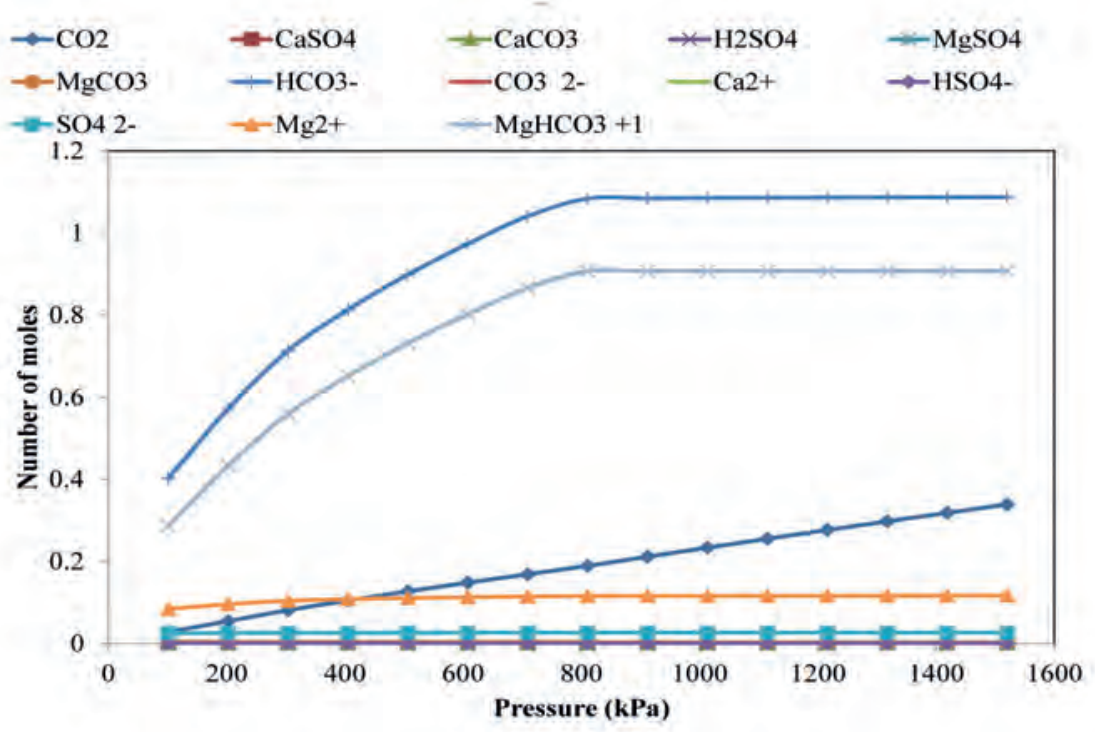

Figure 18

Quantitative speciation modelling in the solid phase $\left(60 \mathrm{~g} / \mathrm{l} \mathrm{Mg}(\mathrm{OH})_{2} ; 5.06 \mathrm{~g} \mathrm{CaSO} \mathrm{C}_{4} \cdot 2 \mathrm{H}_{2} \mathrm{O}\right.$ at $25^{\circ} \mathrm{C}$

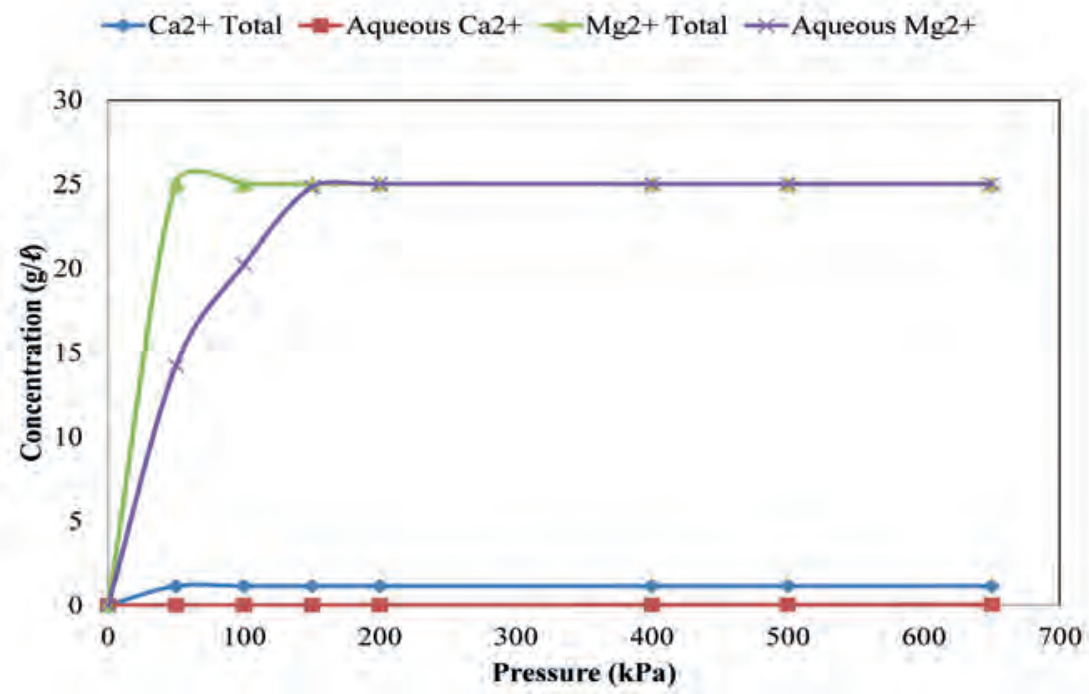

Figure 19

The effect of pressure on the separation of $\mathrm{Mg}(\mathrm{OH})_{2}$ and $\mathrm{CaSO}_{4} \cdot 2 \mathrm{H}_{2} \mathrm{O}$ in contact with $\mathrm{CO}_{2}$ at $5^{\circ} \mathrm{C}\left(60 \mathrm{~g} / \mathrm{l} \mathrm{Mg}(\mathrm{OH})_{2} \cdot 5.06 \mathrm{~g} \mathrm{CaSO} \cdot 2 \mathrm{H}_{2} \mathrm{O}\right)$ 
The calcium sulphate also reacts with bicarbonate ions to form $\mathrm{CaCO}_{3}$ and $\mathrm{HSO}_{4}$. The bisulphate formed will then liberate $\mathrm{H}^{+}$ (Eqs (12) and (14)), which will lower the solution $\mathrm{pH}$ and then promote further dissolution of $\mathrm{CaSO}_{4} \cdot 2 \mathrm{H}_{2} \mathrm{O}$ :

$$
\begin{aligned}
& \mathrm{CaSO}_{4} \cdot 2 \mathrm{H}_{2} \mathrm{O}+\mathrm{HCO}_{3}^{-} \rightarrow \mathrm{CaCO}_{3}+\mathrm{HSO}_{4}^{-}+2 \mathrm{H}_{2} \mathrm{O} \\
& \mathrm{HSO}_{4}^{-} \rightarrow \mathrm{H}^{+}+\mathrm{SO}_{4}^{2-}
\end{aligned}
$$

From the equations above, the solubility of gypsum increases because of an increase in ionic species in solution, thus increasing the interaction between the reacting species that elevates the solubility limit to the formation of both $\mathrm{CaCO}_{3}$ and $\mathrm{Ca}\left(\mathrm{HCO}_{3}\right)_{2}$. The initial dissolution stage of gypsum is attributed to the removal of an unstable layer and fine particles from the crystal surface following the transition state theory while obeying the power law:

$$
R_{\mathrm{diss}}=k_{\mathrm{s}}\left(1-\mathrm{c}_{\mathrm{s}} / c_{\mathrm{sat}}\right)^{\mathrm{n}}
$$

Where $R_{\text {diss }}$ is the dissolution rate, $k_{\mathrm{s}}$ the surface reaction rate constant, $c_{\mathrm{s}}$ is the concentration of the dissolved species at the surface, $c_{\text {sat }}$ is the solubility and $n$ is a constant (Lasaga, 1998).

As the system becomes enriched in $\mathrm{CO}_{2}$, the dissolution rate of $\mathrm{Mg}(\mathrm{OH})_{2}$ could be influenced by its saturation level, $\Omega$ (Rukuni et al., 2012b):

$$
\Omega=\left[\mathrm{Mg}^{2+}\right]\left[\mathrm{OH}^{-}\right] / K_{\mathrm{sp}}
$$

Where $K_{\mathrm{sp}}$ is the solubility product; $T$ is temperature; $S$ is solubility and $p$ is the pressure (Mucci, 1983).

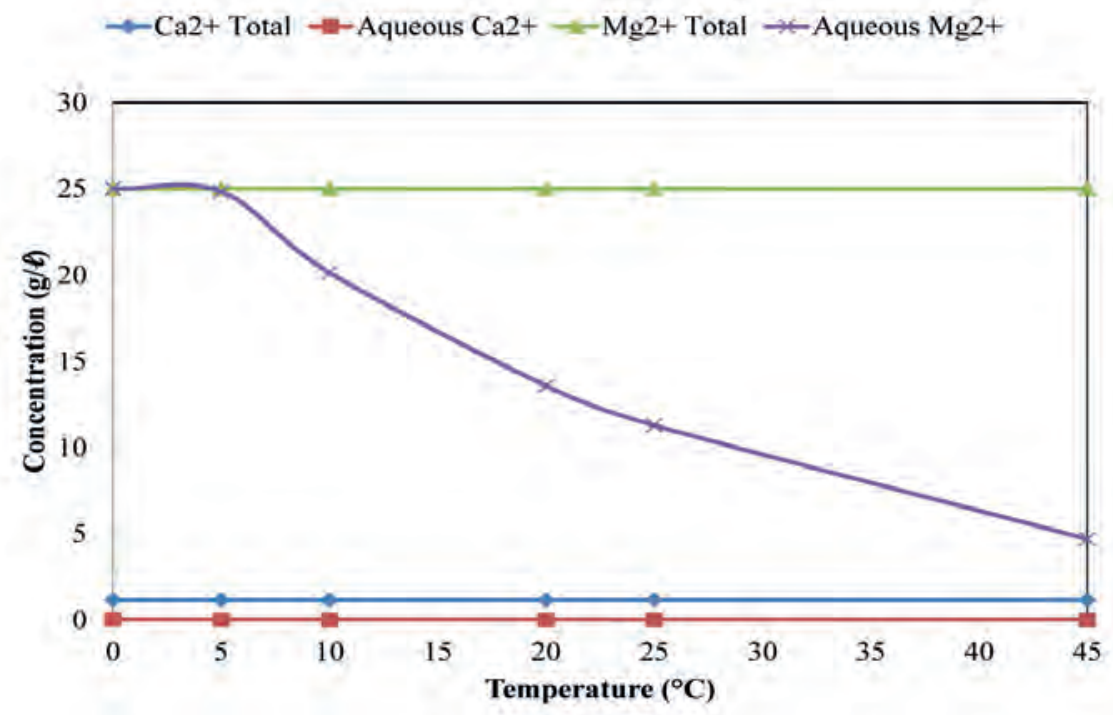

Figure 20

The effect of temperature on the separation of $\mathrm{Mg}(\mathrm{OH})_{2}$ and $\mathrm{CaSO}_{4} \cdot 2 \mathrm{H}_{2} \mathrm{O}$ in contact with $\mathrm{CO}_{2}$ at $150 \mathrm{kPa}\left(6 \mathrm{~g} / \mathrm{l} \mathrm{Mg}(\mathrm{OH})_{2} ; 5.06 \mathrm{~g} \mathrm{CaSO} \mathrm{O}_{4} \cdot 2 \mathrm{H}_{2} \mathrm{O}\right)$

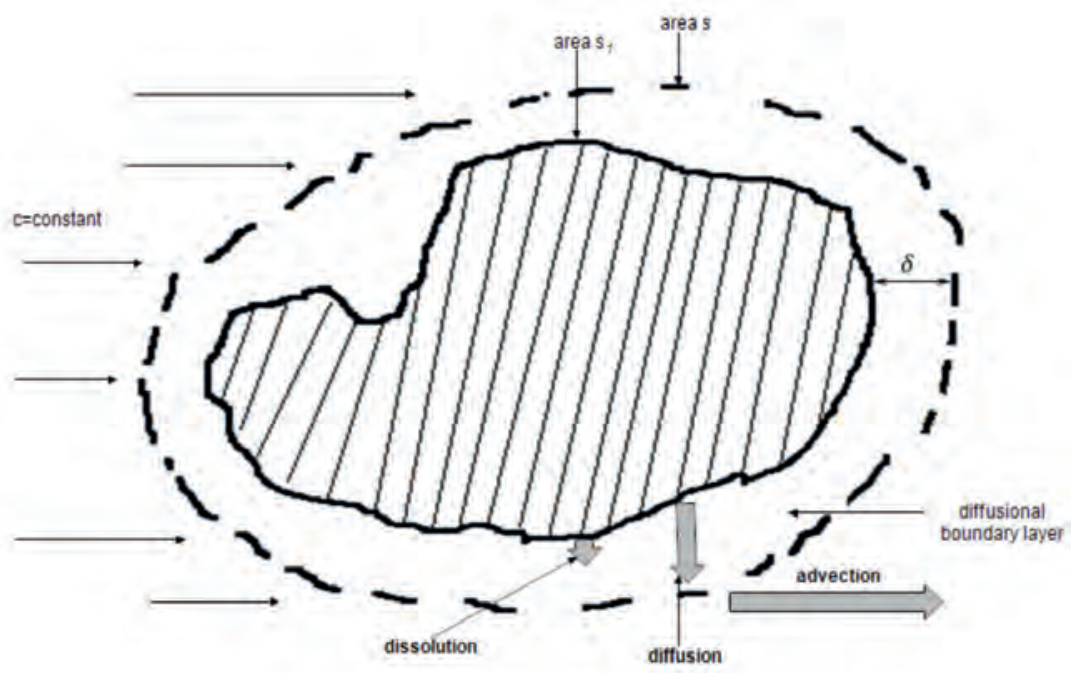

Figure 21

Dissolution mechanism of gypsum in a bulk solution (Colombani, 2008) 
Note: All the square-bracketed species are stoichiometric concentrations (molality or $\mathrm{mol} / \mathrm{kg}$ ) and disregard any complex formation or ion pairs. It is thus necessary to specify not only the $\mathrm{pH}$ scale used in the evaluation of the dissociation constants (Dickson, 1984), but also their dependency on ionic strength, temperature, and pressure.

During the dissolution of $\mathrm{CaSO}_{4} \cdot 2 \mathrm{H}_{2} \mathrm{O}$, a mass transport boundary layer develops in the vicinity of the solid particles and dissolution will then proceed in a manner whereby the ions are firstly unbound from the solid and solvated. The second step is when the ions migrate through the diffusion boundary layer. The concentration is generally considered as linear in this layer and Fick's Law follows:

$$
R_{\text {diff }}=k_{\mathrm{t}}\left(c_{\mathrm{s}}-c\right)
$$

Where $R_{\text {diff }}$ is the diffusion rate, $k_{\mathrm{t}}=D / \delta$ a transport rate constant, $D$ the diffusion coefficient of the dissolved components, $\delta$ the diffusion boundary layer thickness and $c$ is the concentration in the bulk liquid (Lasaga, 1998). The final step is where the ions are advected throughout the solution. These steps are shown in Fig. 21.

Sjöberg and Rickard (1984) studied the dissolution of calcite and gypsum and found that the dissolution of carbonate and sulphate minerals exhibit mixed kinetics where the kinetics are due to both diffusive transport and controlled by chemical reaction. When $R_{\text {diff }}<<R_{\text {diss }}$, the phenomenon of the dissolution kinetics is transport controlled, and when $R_{\text {diff }} \gg R_{\text {diss }}$, the kinetics are reaction based.

Liu and Nancollas (1971) noticed that the rate of dissolution is proportional to the difference between the instantaneous concentration $C$, at time $t$, and the gypsum saturation solubility in water, $C_{\mathrm{s}}$. This statement can be formulated mathematically as follows:

$$
d C / d t=k\left(C_{\mathrm{s}}-C\right)
$$

The value of the saturation concentration of the calcium ions in water can be derived by knowing that $2.5 \mathrm{~kg}$ of gypsum are dissolved in $1 \mathrm{~m}^{3}$ of water. Since the molar mass of gypsum is $172.2 \mathrm{~g} / \mathrm{mol}$, the saturation concentration in $1 \mathrm{~m}^{3}$ of water is equal to $14.52 \mathrm{~mol} / \mathrm{m}^{3}$ (Betti et al., 2008).

Building upon the findings of previous growth and dissolution studies of other mixed sludges, it was concluded that the dissolution rates of these minerals are governed by solvation affinity for the near-surface divalent metals. The results of this study suggest that the dissolution kinetics of sulphates is governed by a similar, but inverse, rate-limiting step. That is, dissolution rates are proportional to the hydration or solvation affinity of metals contained in these structures. In gypsum, the divalent atoms of $\mathrm{Ca}$ are coordinated to join with the $\mathrm{SO}_{4}$ tetrahedra. Rates of gypsum dissolution are also quite rapid and rates are limited by transport control in most conditions (Liu and Nancollas, 1971; Barton and Wilde, 1971). However, initial rates of dissolution appear to be surface reaction controlled, as suggested, by a relatively large activation energy of $40 \mathrm{~kJ} / \mathrm{mol}$ (Liu and Nancollas, 1971).

The separation of $\mathrm{Mg}(\mathrm{OH})_{2}$ and $\mathrm{CaSO}_{4} \cdot 2 \mathrm{H}_{2} \mathrm{O}$ from a $\mathrm{Mg}(\mathrm{OH})_{2}-\mathrm{CaSO}_{4} \cdot 2 \mathrm{H}_{2} \mathrm{O}$ mixed sludge was shown to be feasible by accelerated carbonation. However, it was also noted that $\mathrm{CaSO}_{4} \cdot 2 \mathrm{H}_{2} \mathrm{O}$ will not be recovered as $\mathrm{CaSO}_{4}$ but the calcium will be recovered as $\mathrm{CaCO}_{3}$ while $\mathrm{Mg}(\mathrm{OH})_{2}$ will be recovered as either $\mathrm{MgCO}_{3} \cdot 3 \mathrm{H}_{2} \mathrm{O}, \mathrm{Mg}(\mathrm{OH})_{2}$ or $\mathrm{MgSO} 4 \cdot 7 \mathrm{H}_{2} \mathrm{O}$.
$\mathrm{MgCO}_{3} \cdot 3 \mathrm{H}_{2} \mathrm{O}$ and $\mathrm{Mg}(\mathrm{OH})_{2}$ can be precipitated from $\mathrm{MgHCO}_{3}^{+}$ and $\mathrm{MgOH}^{+}$by lowering the reaction pressure to atmospheric. The $\mathrm{MgCO}_{3} \cdot 3 \mathrm{H}_{2} \mathrm{O}$ and $\mathrm{Mg}(\mathrm{OH})_{2}$ can still be reused in the CSIR-ABC process for the neutralisation of free acid and metal removal during the treatment of acid mine drainage.

The practical, optimal operating conditions for the dissolution process are thus temperatures close to $0^{\circ} \mathrm{C}$ and pressures as close as possible to atmospheric (50 to $200 \mathrm{kPa}$ ), depending on the application. From the reaction equilibrium and the results of this study, it was apparent that decreasing the temperature and lowering $\mathrm{CO}_{2}$ pressures will result in an improved conversion of $\mathrm{Mg}(\mathrm{OH})_{2}$ to $\mathrm{Mg}\left(\mathrm{HCO}_{3}\right)_{2}$. Keeping the pressure low will help in lowering the solubility of the $\mathrm{CaCO}_{3}$, hence increasing the separation rate.

Based on our current application, the recommended optimum operational conditions of temperature and pressure on the separation of $\mathrm{Mg}(\mathrm{OH})_{2}$ and $\mathrm{CaSO}_{4} \cdot 2 \mathrm{H}_{2} \mathrm{O}$ in contact with $\mathrm{CO}_{2}$ is a temperature of $5^{\circ} \mathrm{C}$ and pressure of $150 \mathrm{kPa}$, to yield a 99.34\% $\mathrm{Mg}^{2+}$ recovery as $\mathrm{Mg}\left(\mathrm{HCO}_{3}\right)_{2}$ with $0.05 \% \mathrm{Ca}^{2+}$ impurities as $\mathrm{Ca}\left(\mathrm{HCO}_{3}\right)_{2}$.

Applying the results of this study will contribute to the improvement of the CSIR-ABC process, designed to meet the criteria for maximum value of treated water and by-products, coupled with lowered running and sludge disposal costs. The cost of the separation process is low because all the process raw materials $\left(\mathrm{CO}_{2}\right.$ and the $\mathrm{Mg}(\mathrm{OH})_{2}-\mathrm{CaSO}_{4}-2 \mathrm{H}_{2} \mathrm{O}$ sludge $)$ are waste products of the CSIR-ABC process (Fig. 1). It is also foreseen that the cost can be kept low in other applications by producing $\mathrm{CO}_{2}$ on site by burning coal and scrubbing the off-gases in water rather than purchasing pure $\mathrm{CO}_{2}$.

\section{CONCLUSIONS}

Carbon dioxide can be used for separation of $\mathrm{Mg}(\mathrm{OH})_{2}$ from $\mathrm{CaSO}_{4} \cdot 2 \mathrm{H}_{2} \mathrm{O}$ due to the high solubility of $\mathrm{Mg}\left(\mathrm{HCO}_{3}\right)_{2}$ compared to $\mathrm{CaSO}_{4} \cdot 2 \mathrm{H}_{2} \mathrm{O}$. The optimum separation capacity for the $\mathrm{Mg}(\mathrm{OH})_{2}-\mathrm{CaSO}_{4} \cdot 2 \mathrm{H}_{2} \mathrm{O}$ sludge mixture is $99.34 \% \mathrm{Mg}^{2+}$ and $0.05 \% \mathrm{Ca}^{2+}$ in the aqueous phase when contacted with $\mathrm{CO}_{2}$ at a temperature of $5^{\circ} \mathrm{C}$ and pressure of $150 \mathrm{kPa}$.

The model predictions were in agreement with the experimental findings. Temperature and pressure had a significant impact on the dissolution of the mixed sludges when contacted with $\mathrm{CO}_{2}$

\section{ACKNOWLEDGMENTS}

Financial support from The National Research Foundation's Technology and Human Resources for Industry Program (THRIP) and the use of the laboratory facilities at Tshwane University of Technology are gratefully acknowledged.

\section{REFERENCES}

AL-KHADI MH, AL-JUHANI AM, AL-MUTAIRI SH and GURMEN MN (2011) New insights into the removal of calcium sulphate scale. Saudi Aramco J. Technol. 1 14-51.

BARTON AFM and WILDE NM (1971) Dissolution rates of polycrystalline samples of gypsum and orthorhombic forms of calcium sulphate by a rotating disc method. Trans. Faraday Soc. 67 3590-3597. BETTI D, BUSCARNERA G, CASTELLANZA R and NOVA R (2008) Numerical analysis of the life-time of an abandoned gypsum mine. In: The 12th International Conference of International Association for Computer Methods and Advances in Geomechanics (IACMAG) 1-6 October 2008, Milan, Italy. 
BISHOP DL (1943) Function of carbon dioxide in producing efflorescence on plaster and cement products. J. Res. Natl Bur. Stand. 30 361-366.

CARLBERG BL and MATTHEWS RR (1973) Solubility of calcium sulphate in brine. In: SPE Oil Field Chemistry Symposium, 24-25 May 1973, Denver, Colorado, USA.

COLOMBANI J (2008) Measurement of the pure dissolution rate constant of a mineral in water. Geochim. Cosmochim. Acta 72 5634-5640.

DELOREY J, ALLEN S and MCMASTER L (1996) Precipitation of calcium sulphate during carbonate acidizing: Minimizing the risk. In: Petroleum Society of Canada 47th Annual Technical Meeting, 10-12 June 1996, Calgary, Alberta, Canada.

DICKSON AG (1984) $\mathrm{pH}$ scales and proton-transfer reactions in saline media such as seawater. Geochim. Cosmochim. Acta 48 2299-2308.

EATON AD, CLESCERI LS and GREENBERG AE (eds) (1995) Standard Methods for the Examination of Water and Wastewater. APHA, AWWA and WEF, USA.

KUECHLER R, NOACK K and ZORN T (2004) Investigation of gypsum dissolution under saturated and unsaturated water conditions. Ecol. Modell. 176 1-14.

LASAGA AC (1998) Kinetic theory in the earth sciences, Princeton University Press Princeton, New Jersey, USA.
LIU ST and NANCOLLAS GH (1971) The kinetics of dissolution of calcium sulphate di-hydrate. J. Inorg. Nuclear Chem. 33 2311-2316.

MARTYNOWICS ETMJ, WITKAMP GJ and VAN ROSMALEN GM (1996) The effect of aluminum fluoride on the formation of calcium sulfate hydrates. Hydrometallurgy 41 171-186.

MUCCI A (1983) The solubility of calcite and aragonite in seawater at various salinities, temperatures and 1 atmosphere total pressure. Am. J. Sci. 283 780-799.

RAJU K and ATKINSON G (1990) The thermodynamics of "scale" mineral solubilities. 3. Calcium sulfate in aqueous $\mathrm{NaCl}$. Chem. Eng. Data 35 361-367.

RUKUNI TT, MAREE JP and ZVINOWANDA CM (2012a) Recovery of calcium carbonate from a calcium carbonate-barium sulphate mixed sludge. In: $27^{\text {th }}$ International Conference on Solid Wastes and Technology, 11-14 March 2012, Philadelphia, USA.

RUKUNI TT, MAREE JP and ZVINOWANDA CM (2012b)

Separation of magnesium hydroxide and barium sulphate from abarium sulphate - magnesium hydroxide mixed sludge by carbonation: The effect of temperature. J. Civ. Environ. Eng. 2116. doi:10.4172/2165-784X.1000116.

SJÖBERG EL and RICKARD DT (1984) Calcite dissolution kinetics: surface speciation and the origin of the variable $\mathrm{pH}$ dependence. Chem. Geol. 42 119-136. 